\title{
SELECTION OF FISÁLIS POPULATIONS FOR HIBRIDIZATIONS, BASED ON FRUIT TRAITS ${ }^{1}$
}

\author{
NICOLE TREVISANI ${ }^{2}$, RODOLFO SCHMIT $^{3}$, MATTHEUS BECK ${ }^{3}$, \\ ALTAMIR FREDERICO GUIDOLIN ${ }^{4}$, JEFFERSON LUÍS MEIRELLES COIMBRA ${ }^{5}$
}

\begin{abstract}
The objective of this study was to characterize the genetic variability in fisális populations and select promising parents based on fruit traits. The experimental design consisted of randomized blocks, with six populations. Five plants per treatment were sampled. The evaluated traits were fruit weight, capsule weight, 1000- seed weight and fruit diameter. The data were subjected to multivariate analysis of variance with error specification between and within $(p<0.05)$. Mahalanobis' distance was used as a measure of genetic dissimilarity. Significant differences for the assessed traits were detected between fisális populations. The ratio error among by within indicated no need for sampling within the experimental unit. Dissimilarity was greatest between Lages and Vacaria. The most discriminating traits were capsule weight, fruit weight and fruit diameter. The multivariate contrasts indicated differences between the populations of Vacaria and from Caçador, Lages and Peru, selected for hybridizations.
\end{abstract}

Index Terms: Physalis peruviana L.,genetic variation, selection.

\section{SELEÇÃO DE POPULAÇÕES DE FISÁLISPARA USO EM HIBRIDAÇÕES, BASEADA EM CARACTERES DO FRUTO}

RESUMO - O objetivo do trabalho foi caracterizar a variabilidade genética em populações de fisális e selecionar genitores promissores mediante caracteres relacionados ao fruto. Para tanto, o delineamento utilizado foi o de blocos casualizados, composto por seis populações, com amostragem de cinco plantas da unidade experimental. Os caracteres avaliados foram massa do fruto, massa da cápsula, massa de mil sementes e diâmetros do fruto. Os dados foram submetidos à análise de variância com a especificação do erro entre e dentro $(p<0,05)$. Para estimar a dissimilaridade genética, foi utilizada a distância generalizada de Mahalanobis, e com a técnica de contrastes multivariados foi possível testar as diferenças entre as populações e estimar a contribuição das variáveis para a dissimilaridade. As populações de fisális são diferentes para o conjunto de caracteres avaliados. A relação do erro entre sobre o erro indica a não necessidade de amostragens dentro da unidade experimental. A maior magnitude de dissimilaridade foi entre Lages e Vacaria. Os caracteres responsáveis pela diferença foram massa da cápsula, massa do fruto e diâmetro equatorial do fruto. Os contrastes multivariados apontaram diferença entre a população de Vacaria e as populações de Caçador, Lages e Peru, selecionadas para as hibridizações.

Termos para Indexação: Physalis peruviana L.,variação genética, Seleção.

\footnotetext{
${ }^{1}$ (Trabalho 032-15). Recebido em: 09-01-2015. Aceito para publicação em: 04-08-2015.

${ }^{2}$ Engenheira Agrônoma. Doutoranda no Curso de Produção Vegetal, UDESC/CAV. Bolsista de Pesquisa Capes. Lages-SC E-mail: nicoletrevisani88@gmail.com.

${ }^{3}$ Acadêmicos do Curso de Agronomia, UDESC/CAV. Lages-SC. E-mail: rodolfoschmit09@gmail.com; mattheusbeck@hotmail.com. ${ }^{4}$ Engenheiro Agrônomo. Orientador. Professor do Departamento de Agronomia, UDESC/CAV. Lages-SC. E-mail: altamirguidolin@ gmail.com.

${ }^{5}$ Engenheiro Agrônomo. Co-orientador. Professor do Departamento de Agronomia, UDESC/CAV. Lages-SC. Bolsista de Produtividade em Pesquisa CNPq. E-mail: coimbrajefferson@gmail.com.
} 


\section{INTRODUCTION}

Fisális (Physalis peruviana L.) is native to the Andean region and belongs to the nightshade family. The basic chromosome number of the genus Physalis is $\mathrm{n}=12$, and the majority of the species are diploid; of the cultivated species, only P. peruviana is tetraploid (NOHRA et al., 2006). Pollination is predominantly by allogamy (SANTANA; ANGARITA, 1999), although selfing can occur (FISCHER et al., 2014). The fruits are yellow-orange, have a diameter of 10 to $35.5 \mathrm{~mm}$ and an aromatic and sweet flavor. Consumption can be fresh, canned or used for decoration as well. The high vitamins A, B1, B2, B12 and $\mathrm{C}$ levels make it an interesting nutritional source (BRIONES-LABARCA et al., 2013).

Fisális is grown mainly in Colombia (HERRERA et al., 2012). In Brazil, it was introduced as cash crop in 1999, in São Paulo State, and later expanded to the south of the country. The good adaptation of the crop to the soil and climatic conditions and acceptance of the fruit were essential for the success of the specie in Brazil. This country is a potential producer of fisális, with prospects to become an exporter of this fruit. However, any crop production chain depends, among a series of factors, on the efforts of research institutions invested in breeding work. Most of the research is intended to develop cultivation techniques, while few studies are focused on breeding.

Characterization studies of accessions, carried out in Colombia (LAGOS et al., 2007), represented the basis for the beginning of a breeding program different fisális accessions were characterized by Leiva-Brondo et al. (2001), who detected genetic differences in fruit yield and quality, which are key traits to be exploited by breeding of the species. In Brazil, the cultivated populations are grown from seeds of unknown origin, with no prior knowledge about the genetic potential they contain. This fact can be confirmed by the lack of registered seeds (MAPA, 2015), reinforcing the importance of initiating a breeding program.

The genetic potential of a species depends largely on the availability of genetic variability (CECCARELLI, 2015). Genetic variability is the basis of breeding and can facilitate the selection of productive populations adapted to local conditions (WAMSER et al., 2012). Based on genetic resources, breeders can select populations with large distance or with pre-defined characteristics, perfecting cloning work and mass multiplication of plants with the desired traits or combinations thereof (LIGARRETO et al., 2005). In characterization studies, morphological descriptors are used to estimate the variability, which is the first step to deepen the knowledge of the genetic potential of a species.

In this sense, the purpose of this study was to characterize the genetic variability in fisális populations and select promising parents by fruit-related traits.

\section{MATERIAL AND METHODS}

The study was carried out in the experimental area of Instituto de Melhoramento e Genética Molecular of the Universidade do Estado de Santa Catarina - UDESC in Lages, SC (lat $27^{\circ} 48^{\prime} \mathrm{S}$, long $50^{\circ} 19^{\prime} \mathrm{W}$, mean $916 \mathrm{~m}$ asl). The climate is $\mathrm{Cfb}$ (temperate climate with cool summer) and the mean annual temperature $15^{\circ} \mathrm{C}$, with an average rainfall of $1.500 \mathrm{~mm}$.

The data were adopted from an experiment consisting of six fisális populations, from Fraiburgo, Vacaria, Caçador, Lages, Colombia, and Peru. These populations are representative of the genetic variability of the varieties cultivated in municipalities in the Midwest region and Planalto Serrano of the State of Santa Catarina. Seeds were taken randomly from ripe fruits from each population, sown in trays with commercial substrate for nightshade plants, and maintained in a greenhouse. Seedlings were planted in the field 45 days after sowing in trays, at a plant height of 15 to $20 \mathrm{~cm}$.

The experiment was arranged in a randomized block design with two replications. Five plants per experimental unit were sampled. The measured traits were fruit weight without capsule (FW, in g) capsule weight (CW, in g) 1000- seed weight (TSW, in $\mathrm{g}$ ), equatorial fruit diameter (EFD, in $\mathrm{mm}$ ) and polar fruit diameter (PFD, in $\mathrm{mm}$ ).

For data analysis, multivariate variance was comprehensively tested $(\mathrm{p}<0.05)$ by Wilks' lambda criterion, by the Generalized Linear Model (GLM) procedure of SAS 9.2. In the analysis, the error between and the error within were considered. The following statistical model was used: : where, $\mathrm{Y}_{\mathrm{ij}}$ indicates the set of assessed traits; $\mu$ is the general mean; $b_{i}$ : the block effect; pop $p_{j}$ : the effect associated with the $j_{-}{ }^{\text {th }}$ population level; $e_{i j}$ : effect of the error between (experimental error); $\mathrm{d}_{\mathrm{ij} \text { l }}$ : effect of the error within (sampling error), which are data obtained by evaluation of the plants of the experimental units.

The genetic dissimilarity was estimated by the coefficients of Mahalanobis' distance $\left(D^{2}\right)$ between all pairs of populations. Based on the genetic distance matrix, a dendrogram was constructed using the unweighted pair-group method based on 
arithmetic averages (UPGMA) grouping method. The adjustment between the distance matrix and the dendrogram was estimated by the cophenetic correlation coefficient $\left(\mathrm{r}_{\text {cof }}\right)$ (SOKAL E ROHLF, 1962). The procedure of multivariate contrasts considering Wilks' lambda test $(\mathrm{p}<0.05)$ was performed to test for significance between the populations of interest. With this procedure, the relative contribution of traits could be determined by standardized canonical coefficients. The GLM procedure of SAS 9.2 was used to test the contrasts.

\section{RESULTS AND DISCUSSION}

The result of the multivariate analysis of variance showed a significant difference for the population (at $5 \%$ error probability), indicating the existence of variability between at least two fisális populations (Table 1). Thus, the origin of variation between fisális populations as well as which traits are contributing to the variation are addressed here. When the average vectors of the treatments show significant variation, complex inferences must be derived, requiring multivariate techniques. It is worth emphasizing that the multivariate analysis of variance considers the phenomenon of mutual dependence between the response variables, which was not taken into consideration in the univariate analysis (COIMBRA et al., 2007a).

The occurrence of variability can be explained by different selection pressures (natural and artificial) to which each population was naturally subjected, inducing changes in genotype frequencies. Therefore, it is of paramount importance to know the genetic variability, which allows the exploitation of the genetic potential of the population for the selection and fixation of agronomically important traits (RAMALHO et al., 2012). Plant breeders are interested in wide genetic variability for the application of selective processes resulting in significant genetic gains (ALLABY et al., 2014).

In the analysis of variance the ratio of the variance of error among by the variance of error within was not significant (Table 1). Therefore, the variation affecting the sample values was purely random and evenly distributed between the five plants in the experimental unit. Therefore, sampling within the unit is not indicated, since the variation is evenly distributed in the unit and contains no additional information to be exploited (SILVA, 2003).

To determine the genetic distance between one population and the other, the coefficients of Mahalanobis' distance were estimated (Table 2). The population from Lages diverged significantly from the other populations, demonstrating that the trait set allowed a discrimination of this population (Table 2). The population with greatest genetic distance from Lages was Vacaria (4.641) and therefore, less similar populations. The population of Vacaria was also dissimilar from Caçador (1.192) and Peru (2.210). The greater genetic distance between parents can increase the chances of genetically superior combinations (ZAMORA-TAVARES et al., 2015). With the complementation of different alleles the hybrid vigor can be exploited, and for fisális this seems to be a viable alternative since vegetative propagation provides efficient results (MORENO et al., 2009). In addition, artificial hybridization ensures a high number of seeds per fruit (200 to 250 seeds).

The populations from Colombia and Peru did not differ by the distance of Mahalanobis (Table 2), this similarity may be due to the common origin of these populations. In spite of being a species with predominance of allogamy, the gene pool for the traits may be similar in the population of Colombia and Peru. In a study on the morphological characterization of Physalis peruviana, of Betancourt et al. (2008) in Colombia, 10 (ten) fisális accession with very close phenotypic distances were identified, forming a group with minor differences. This is possibly a single accession, with wide dispersion in the Andean region.

The visual analysis based on the dendrogram supports the results of genetic dissimilarity between the population of Lages and the other populations (Figure 1). A cut performed at a distance of $70 \%$ (x-axis) formed a dissimilarity group of the population from Lages. The dendrogram also showed the similarity between Colombia and Peru, by the close grouping. In addition, the cophenetic correlation coefficient $\left(\mathrm{r}_{\text {cof }}\right)$ had a magnitude of 0.76 . The more this value approaches 1 , the smaller is the distortion caused by the population grouping based on UPGMA (CARGNELUTTI-FILHO et al., 2010). Comparisons between the mean vectors generated by multivariate contrasts $(p<0.05)$, showed differences only between the combinations involving the population of Vacaria (Table 3), differing from those from Caçador, Lages and Peru. The range of distances between the populations of Lages and Vacaria, proved by Mahalanobis' distance, suggested the selection of both populations for future hybridizations. The choice of parents for hybridization with a view to expanding the species variability must take into account the genetic divergence, per se performance of the parents and the allelic complementation (DA COSTA et al., 2014).

Nevertheless, the traits that contributed to the variation among populations were identified 
using standardized canonical coefficients (Table 3). Among the significant contrasts, the traits that contributed to the differentation were CW, FW and EFD. Conversely, standardized canonical coefficients with negative values can be interpreted similarly, but with the opposite direction to the effect, i.e., a negative value reduces the effect of the trait in question (COIMBRA et al., 2007b). Thus, the traits TSW and PFD contributed to the similarity between the population of Vacaria with those from Caçador, Lages and Peru.

The results showed that the traits responsible for discriminating populations can be prioritized in fisális breeding for the region of the highland plateau of Santa Catarina. In a study of morphological characterization of Physalis peruviana accessions, Bonilla and Espinosa (2005) pointed out that the fruit weight and diameter were decisive to identify promising accessions for fresh market consumption and the fruit processing industry. Among the important traits for selection, fruit weight is considered the key trait for marketing (ANZANELLO et al., 2013). The commercial value of fruits is related to appearance, size and post-harvest quality (TAVARINI et al. 2008)

TABLE 1 - Multivariate analysis of variance $(p<0.05)$, indicating the degrees of freedom of the numerator (DFN) and denominator (DFD), Wilks' lambda criterion, value of the F test and significance for the traits: fruit weight, capsule weight, 1000- seed weight, equatorial fruit diameter and polar fruit diameter, among six Fisális populations, with the utilization of errors to test the hypothesis.

\begin{tabular}{lcccc}
\hline Source of variation & DFN & DFD & $\boldsymbol{\Lambda}$ value & F value \\
\hline Block & 5 & 1 & 0.001 & $123.91^{\text {ns }}$ \\
Population & 25 & 5.21 & 0.001 & $8.37^{*}$ \\
Error among & 25 & 164.95 & 0.606 & $0.95^{\mathrm{ns}}$ \\
\hline
\end{tabular}

${ }^{1 / *}$ : significant at $5 \%$ error probability. ${ }^{\mathrm{n} s}$ : non significant. Null hypothesis tested: $\mathrm{H}_{0}: \mu_{1}=$ $\mu_{2}=\ldots=\mu_{\mathrm{k}}$

TABLE 2 - Estimates of the genetic divergence between two Fisális populations, established by the coefficients of the Mahalanobis' distance $\left(\mathrm{D}^{2}\right)$, considering the traits fruit weight, capsule weight, 1000- seed weight, equatorial fruit diameter and polar fruit diameter.

\begin{tabular}{|c|c|c|c|c|c|}
\hline Population & Vacaria & Caçador & Lages & Colômbia & Peru \\
\hline Fraiburgo & $1.022^{\mathrm{ns}}$ & $0.558^{\mathrm{ns}}$ & $3.313^{*}$ & $0.514^{\mathrm{ns}}$ & $0.691^{\mathrm{ns} 1}$ \\
\hline Vacaria & & $1.195^{*}$ & $4.641^{*}$ & $0.853^{\mathrm{ns}}$ & $2.21^{*}$ \\
\hline Caçador & & & $1.617^{*}$ & $0.206^{\mathrm{ns}}$ & $0.372^{\mathrm{ns}}$ \\
\hline Lages & & & & $1.972^{*}$ & $1.375^{*}$ \\
\hline Colômbia & & & & & $0.477^{\mathrm{ns}}$ \\
\hline
\end{tabular}

${ }^{1 / *}:$ significant at $5 \%$ error probability. ${ }^{\text {ns/ }}$ : non significant. 
TABLE 3 - Multivariate contrasts obtained the information of generalized Mahalanobis' distances $\left(\mathrm{D}^{2}\right)$ with their standardized canonical coefficients and statistics of the traits likelihood ratio: capsule weight $(\mathrm{CW})$, fruit weight (FW), weight of thousand seeds (TSW) equatorial diameter of fruits (EFD), polar diameter of fruits (PFD).

\begin{tabular}{lcccccc}
\hline Contrasts & CW & FW & TSW & EFD & PFD & F \\
\hline Fraiburgo vs Lages & 0.569 & 0.866 & -0.502 & -0.444 & -0.374 & $0.115^{\mathrm{ns} 1}$ \\
Vacaria $_{\text {vs }}$ Caçador & 0.193 & 0.794 & -0.129 & 0.355 & -0.433 & $0.025^{*}$ \\
Vacaria $_{\text {vs }}$ Lages & 0.339 & 0.709 & -0.393 & 0.356 & -0.338 & $0.001^{*}$ \\
Vacaria $_{\text {vs }}$ Peru & 0.056 & 0.608 & -0.370 & 0.543 & -0.352 & $0.002^{*}$ \\
Caçador $_{\text {vs }}$ Lages & 0.493 & 0.156 & -0.781 & 0.176 & 0.046 & $0.751^{\mathrm{ns}}$ \\
Lages $_{\text {vs }}$ Colômbia & 0.492 & 0.634 & -0.192 & 0.362 & -0.504 & $0.416^{\mathrm{ns}}$ \\
Lages $_{\text {vs }}$ Peru & 0.930 & 0.241 & -0.054 & -0.434 & 0.029 & $0.596^{\mathrm{ns}}$ \\
\hline
\end{tabular}

$\overline{1 / *}^{*}$ : significant at $5 \%$ error probability. ${ }^{\mathrm{ns} /}$ : non significant.

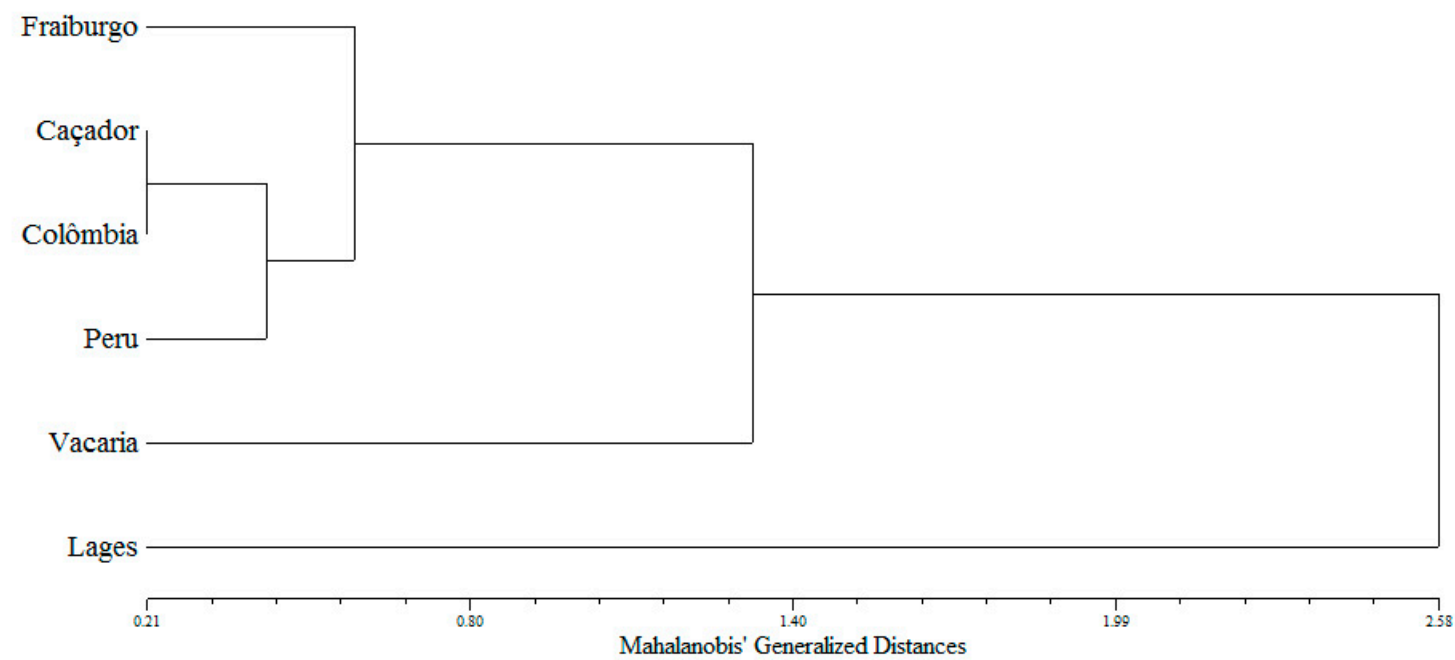

FIGURE 1- Dendrogram illustrating the dissimilarity pattern, established by the UPGMA clustering method based on Mahalanobis' generalized distances for six Physalis populations. 


\section{CONCLUSIONS}

The fisális populations analyzed in this study differ genetically. There is homogeneity within fisális populations, indicating that sampling within plots is unnecessary. Crosses between the population of Vacaria with populations of Caçador, Lages and Peru are recommended, to obtain segregating fisális populations and to possibly exploit hybrid vigor. Hybridizations between individuals of these populations could give rise to superior individuals from parents that are genetically different for the studied traits.

\section{REFERENCES}

ALLABY, R.G.; DORIAN Q.F.; JAMES L.K. The limits of selection under plant domestication. Coventry: University of Warwick, 2014. p.1403-1244, 2014. Disponível em: $<\underline{\text { http: } / /}$ arxiv.org/ftp/arxiv/papers/1403/1403.1244.pdf $>$.

ANZANELLO, R.; DE SOUZA, P.V.D.; SANTAROSA, E.; PEZZI, E. Tamanho de fruto em quivizeiros em função do número de sementes. Pesquisa Agropecuária Gaúcha, Porto Alegre, v.19, n.1/2, p.102-111, 2013.

BETANCOURT, M.L.B.; PIEDRAHÍTA, K.E.; TERRANOVA, A.M.P.; AMARILES, H.D.V.; FLÓREZ, J.E.M. Caracterizacion morfológica de 46 accesiones de uchuva del banco de germoplasma de la Universidad Nacional de Colombia Sede Palmira. Acta Agronomica, Palmira, v.57, n.2, p.101-108, 2008.

BONILLA, M.L.; ESPINOSA, K. Colección, evaluación fenotípica y molecular de poblaciones de uchuva Physalis peruviana L. 2003. 75 f. Monografia (Trabajo grado) - Facultad de Ingeniería Agronómica, Universidad Nacional de Colombia, Palmira, 2003.

BRIONES-LABARCA, V.; GIOVAGNOLIVICUNA, C.; FIGUEROA-ALVAREZ, P.; QUISPEFUENTES, I.; PÉREZ-WON, M. Extraction of $\beta$-Carotene, Vitamin $\mathrm{C}$ and Antioxidant Compounds from Physalis peruviana (Cape Gooseberry) Assisted by High Hydrostatic Pressure. Food and Nutrition Sciences, Irvine, v.4, p.109-118, 2013.
CARGNELUTTI-FILHO, A.; RIBEIRO, N.D.; BURIN, C. Consistência do padrão de agrupamento de cultivares de feijão conforme medidas de dissimilaridade e métodos de agrupamento. Pesquisa Agropecuária Brasileira, Brasília, v.45, n.3, p.236243,2010

CECCARELLI, S. Efficiency of plant breeding. Crop Science, Madison, v.55, p.87-97, 2015.

CHAUTÁ-MELLIZO, A.; CAMPBELL, S.A.; BONILLA, M.A. Effects of natural and artificial pollinatin on fruit and offspring quality. Basic and Applied Ecology, Jena, v.13, p.524-532, 2012.

COIMBRA, J.L.M.; SANTOS, J.C.P.; VICENTE, A.M.; BARZOTTO, I. Técnicas multivariadas aplicadas ao estudo da fauna do solo: contrastes multivariados e análise discriminante canônica. Revista Ceres, Viçosa, MG, v.53, p.270-276, 2007b.

COIMBRA, J.L.M.; SCHWANTES, D.; BERTOLDO, J.G.; KOPP, M.M. Introducion of genetic variability in oat. Crop Breeding and Applied Biotechnology, Viçosa, MG, v.7, n.3, p.212-220, 2007a.

COSTA, J.O.; CREMASCO, J.P.G.; MATIAS, R.G.P.; DA SILVA, D.F.P.; SALAZAR, A.H.; BRUCKNER, C.H. Divergência genética entre populações de pessegueiro baseada em características da planta e do fruto. Ciência Rural, Santa Maria, v.44, n.10, p.1770-1775, 2014.

FISCHER, G.; ALMANZA-MERCHÁN, P.J.; MIRANDA, D. Importancia y cultivo de la uchuva. Revista Brasileira de Fruticultura, Jaboticabal, v.36, n.1, p.001-015, 2014.

HERRERA, A.M.M.; FISCHER, G.; CHÁCON, M.I.S. Agronomical evaluation of cape gooseberries (Physalis peruviana L.) from central and northeastern Colombia. Agronomía Colombiana, Bogotá, v.30, n.1, p.15 - 24, 2012.

LAGOS, T.C.; CRIOLLO, H. Análise combinatória de algumas características do fruto de Physalis peruviana L. Agronômica Colombiana, Bogotá, v.25, n.1, 36-37, 2007.

LEIVA-BRONDO, M.; PROHENS, J.; NUEZ, F. Genetic analysis indicate superiority of performance of cape gooseberry (Physalis peruviana L.) hybrids. Journal of New Seeds, Binghamton, v.3, n.3, p.7184, 2001. 
LIGARRETO, G.A.; LOBO, M.; CORREA, A. Recursos genéticos del género Physalis en Colombia. In: FISCHER, G. (Ed.). Avances en el cultivo, poscosecha y exportación de la uchuva (Physalis peruviana L.) en Colombia. Bogotá: Universidad Nacional de Colombia, 2005. p.9-53.

MAPA. Serviço Nacional de Proteção de Cultivares - SNPC. 2015. Disponível em: < http://extranet. agricultura.gov.br/php/snpc/cultivarweb/cultivares protegidas.php $>$. Acesso: 23 jun. 2015.

MORENO, H.N.; HERRERA, J.G.A.; BALAGUERA-LÓPEZ, H.E.; FISCHER, G. Propagación asexual de uchuva (Physalis peruviana L.) em diferentes sustratos y a distintos niveles de auxina. Agronomía Colombiana, Bogotá, v.27, n.3, p.341-348, 2009.

NOHRA, C.; RODRÍGUEZ, C. Estudio de la diversidad citogenética de Physalis peruviana L. (Solanaceae). Acta Biológica Colombiana, Bogotá, v.11, p.75-85, 2006.

RAMALHO, M.A.P.; SANTOS, J.B.; PINTO, C.A.B.P.; SOUZA, E.A.; SOUZA, J.C. Genética na agropecuária. 5.ed. Lavras: UFLA, 2012.566 p.

SANTANA, G.; ANGARITA, A. Regeneración adventicia de somaclones de uchuva. Agronomia Colombiana, Bogotá, 1999. Disponivel em: $\leq \mathrm{http}: / /$ www.revistas.unal.edu.co/index.php/agrocol/article/ view $/ 25620 / 0>$.
SILVA, J.G.C. Delineamentos experimentais simples. In: Estatística experimental: análise estatística de experimentos. UFPel, Pelotas, 2003. p.285-318.

SOKAL, R.R.; ROHLF, F.J. The comparison of dendrograms by objective methods. Taxon, Berlin, v.11, n.1, p.30-40, 1962.

TAVARINI, S. et al. Preliminary characterisation of peach cultivars for their antioxidant capacity. International Journal of Food Science and Technology, Oxford, v.43, p.810-815, 2008.

WAMSER, G.H.; ARRUDA, B.; STINGHEN, J.C.; ROZZETTO, D.S.; BERTOLDO, J.G.; GUIDOLIN, A.F.; COIMBRA, J.L.M. Caracterização e estimativa da variabilidade genética de genótipos de cebola. Horticultura Brasileira, Brasília, v.30, p.327-332, 2012.

ZAMORA-TAVARES, P.; VARGAS-PONCE, O.; SÁNCHEZ-MARTÍNEZ, J.; CABRERA-TOLEDO, D. Diversity and genetic struture of the husk tomato (Physalis philadelphica Lam.) in Western Mexico. Genetic Resources and Crop Evolution, Dordrecht, v.62, n.1, p.141-153, 2015. 